\title{
Methane at the NW of Weddell Sea, Antarctica
}

\author{
R. A. del Valle, ${ }^{1}$ E. Yermolin, ${ }^{1}{ }^{\text {J. }}$ Chiarandini, ${ }^{2}$ A. Sanchez Granel, ${ }^{3}$ and J. C. Lusky ${ }^{2}$ \\ ${ }^{1}$ Instituto Antártico Argentino, 25 de Mayo 1143, San Martín, Provincia de Buenos Aires, Argentina \\ ${ }^{2}$ Dirección Nacional del Antártico, Balcarce 290, $2^{\circ}$ Piso, C1064ABR Ciudad Autónoma de Buenos Aires, Argentina \\ ${ }^{3}$ Universidad del Salvador, Av. Callao y Córdoba, C1023AAB Ciudad Autónoma de Buenos Aires, Argentina
}

Correspondence should be addressed to R. A. del Valle; kings_foil@hotmail.com

Received 16 August 2016; Revised 14 November 2016; Accepted 1 December 2016; Published 13 February 2017

Academic Editor: Umberta Tinivella

Copyright (c) 2017 R. A. del Valle et al. This is an open access article distributed under the Creative Commons Attribution License, which permits unrestricted use, distribution, and reproduction in any medium, provided the original work is properly cited.

The presence of gaseous hydrocarbons (from methane to n-pentane) in the seabed sediments and the bubbling of methane may suggest the presence of gas accumulations in the substrate of the NW Weddell Sea, Antarctica. The release of methane from the frozen ocean substrate adjacent to Seymour Island would be linked to climate instability during Late Cenozoic, when vast areas of the Antarctic continental shelf were flooded during the marine transgression that occurred c. 18,000 years ago, after the Last Glacial Maximum (LGM). As the ice melted, the sea again occupied the regions which it had abandoned. As the transgression was relatively rapid, the sub-air relief was not destroyed but was submerged and the ground had frozen (permafrost) along with it. Thus, the heat flow from the sea to the marine substrate, now flooded, would have destabilized frozen gas accumulations, which were originally formed into terrestrial permafrost during the LGM, similarly to what would have happened in the Arctic.

\section{Introduction}

Gases that trap heat in the atmosphere are called greenhouse gases, and methane is one of them. Methane emissions cause c. $25 \%$ of the current global warming. While methane does not linger as long in the atmosphere as carbon dioxide, it is initially far more devastating to the climate because of how effectively it absorbs heat. In the first two decades after its release, methane is 84 times more powerful than carbon dioxide [1].

1.1. Objectives. This paper is aimed at briefly presenting and discussing the occurrence of methane gas in Antarctica under two facts: (I) the concentrations of methane (C1) together with other alkane aliphatic hydrocarbons of single bonds, from ethane (C2) to pentane (C5), found in seabed sediments off the northern coast of Seymour Island (Isla Marambio) and the NW extreme of the Weddell Sea, Antarctica (Figure 1), and (II) the natural bubbling of methane observed off the Seymour Island coast (Bouchard Zone, Figure 1; see the supplemental video in Supplementary Material available online at https://doi.org/10.1155/2017/5952916).
1.2. Working Area. The research was conducted in two marine sectors of Antarctica with different characteristics: one of shallow waters, located in Admiralty Sound (Estrecho Bouchard), off the northern coast of Seymour Island, and the other characterized by deeper waters located offshore at about $70 \mathrm{~km}$ to the northeast of the island (Figure 1).

The area named "Bouchard zone" extends about $100 \mathrm{~km}^{2}$ and the area called "Weddell zone" about $3,000 \mathrm{~km}^{2}$. Field activities were developed during austral summers of 1994, $1995,1997,1998,2011$, and 2015, when the region was largely covered by sea ice and icebergs, which hampered systematic sampling in both sectors. For this reason, the distribution of samples at seabed became completely irregular (Figure 1) and the density of samples actually is quite low.

Alkane aliphatic hydrocarbons of single bonds were analyzed at Bouchard and Weddell zones, 88 and 54 samples, respectively (Table 1), spread over $100 \mathrm{~km}^{2}$ and $3,000 \mathrm{~km}^{2}$, resulting in meager 0.88 samples $/ \mathrm{km}^{2}$ and 0.018 samples $/ \mathrm{km}^{2}$, respectively.

1.3. Geological Frame. The working area (Figure 1) is located within an Antarctic site of sedimentary accumulation, James 
TABLE 1: Summary of analyses of C1 to C5 of sediment samples from the Antarctic seabed.

(a) Bouchard zone (Figure 1)

\begin{tabular}{|c|c|c|c|c|c|c|c|}
\hline $\begin{array}{l}\text { Number of samples } \\
88\end{array}$ & $\begin{array}{c}\mathrm{C} 1 \\
(\mathrm{ppm}) \\
\end{array}$ & $\begin{array}{c}\mathrm{C} 2 \\
(\mathrm{ppm}) \\
\end{array}$ & $\begin{array}{c}\mathrm{C} 3 \\
(\mathrm{ppm}) \\
\end{array}$ & $\begin{array}{c}\mathrm{C} 4 \\
(\mathrm{ppm}) \\
\end{array}$ & $\begin{array}{l}\mathrm{n}-\mathrm{C} 4 \\
(\mathrm{ppm}) \\
\end{array}$ & $\begin{array}{c}\mathrm{C} 5 \\
(\mathrm{ppm})\end{array}$ & $\begin{array}{l}\mathrm{n}-\mathrm{C} 5 \\
(\mathrm{ppm})\end{array}$ \\
\hline Maximum & $9,995.63$ & 49.25 & 36.71 & 11 & 6.4 & 2.32 & 0.28 \\
\hline Minimum & 115.82 & 0.03 & 4.81 & 0.17 & 2.77 & 0.07 & 0.06 \\
\hline Average & 423.31 & 21.14 & 10.49 & 4 & 2.77 & 0.66 & 0.25 \\
\hline${ }^{1} R$ & \multicolumn{2}{|c|}{ Maximum $=41$} & \multicolumn{2}{|c|}{ Minimum $=2$} & \multicolumn{3}{|c|}{ Average $R=c .23$} \\
\hline${ }^{2} \% \mathrm{Cl}$ & \multicolumn{2}{|c|}{ Maximum $=99.89 \%$} & \multicolumn{2}{|c|}{ Minimum $=63.44 \%$} & \multicolumn{3}{|c|}{ Average $\% \mathrm{Cl}=c .89 \%$} \\
\hline
\end{tabular}

(b) Weddell zone (Figure 1)

\begin{tabular}{lcccccc}
\hline $\begin{array}{l}\text { Number of samples } \\
54\end{array}$ & $\begin{array}{c}\mathrm{C} 1 \\
(\mathrm{ppm})\end{array}$ & $\begin{array}{c}\mathrm{C} 2 \\
(\mathrm{ppm})\end{array}$ & $\begin{array}{c}\mathrm{C} 3 \\
(\mathrm{ppm})\end{array}$ & $\begin{array}{c}\mathrm{C} 4 \\
(\mathrm{ppm})\end{array}$ & $\begin{array}{c}\mathrm{n}-\mathrm{C} 4 \\
(\mathrm{ppm})\end{array}$ & $\begin{array}{c}\mathrm{C} 5 \\
(\mathrm{ppm})\end{array}$ \\
\hline Maximum & $1,753.87$ & 86.65 & 64.06 & 22.75 & 19.28 & 14.06 \\
$(\mathrm{ppm})$
\end{tabular}

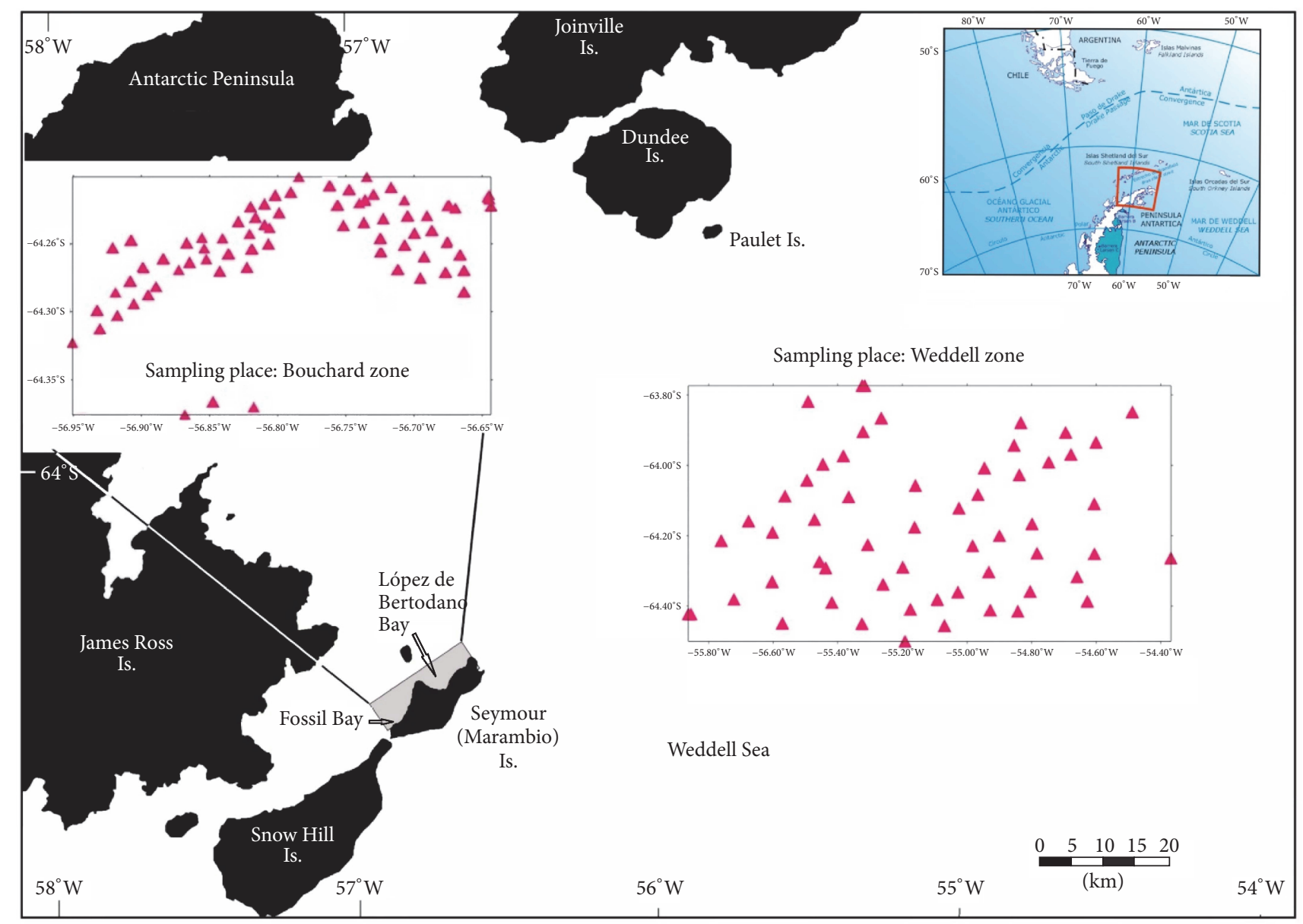

FIGURE 1: Working areas at the NW Weddell Sea, Antarctica. Small triangles (red triangle) indicate sampling places at Bouchard and Weddell zones. Bouchard zone is enlarged due to the small scale of the map, while Weddell zone is in the right scale. 
Ross Basin [2], which is a "subbasin" comprising the northern part of a larger basin named Larsen Basin [3] that was developed behind a volcanic arc (back-arc basin) during most of the Mesozoic and Cenozoic periods. Within this basin, over 6,000 meters of thick clastic sediments, mostly of volcanic origin, were deposited.

Cretaceous and Paleogene sediments, which belong to Marambio and Seymour stratigraphic groups, respectively, crop out at Seymour Island. These sediments correspond to the so-called "shallow play zone" described by Macdonald et al. [4]. He inferred, by indirect geophysical methods (i.e., seismic reflection profiles), that here shallow hydrocarbon reservoirs would potentially be small and contain mainly gas, although the quality of these reservoirs would be higher than that at other deeper levels.

Basaltic rocks of the Miocene-Recent James Ross Island Volcanic Group (JRIVG, [5]) crop out at most of the neighboring islands of James Ross Island Group.

The permafrost layer reaches a thickness of $c .250 \mathrm{~m}$ at Seymour Island [6]. Fukuda et al. [7] defined, at this place, three levels of marine/glacimarine terraces: (1) La Meseta, (2) Sub-Meseta, and (3) Larsen Terrace. The former is the lowest, with $30-35 \mathrm{~m}$ asl and an age of $2,910 \pm 120$ years BP, and was obtained in a layer of algae from the bottom of the terrace at c. $3 \mathrm{~m}$ asl.

According to Sloan et al. [8], two seismostratigraphic units would be present at the deep marine substrate of Weddell zone (Figure 1): (1) the Unit "U3" (reflections dipping $3^{\circ}-5^{\circ} \mathrm{E}-\mathrm{SE}$, Cretaceous-Oligocene?) and (2) the Unit "U4" (chaotic reflections, Jurassic vulcanites?). Samples from the deeper seabed (289-556 $\mathrm{m}$ below sea level) analyzed in this study were obtained in the domain of these two units of the substrate, inferred by high resolution seismic reflection surveys.

The study area, from a structural point of view, is placed to the north of a major counterclockwise strike-slip fault zone, located c. $25-35 \mathrm{~km}$ SE of the eastern coast of Snow Hill and Seymour islands $[8,9]$. This fracture zone is parallel to the eastern edge of Antarctic Peninsula and its origin is assigned to tectonic movements which probably occurred during the Oligocene [8]. Due to its relatively old age, this structure would have no influence in the present study.

1.4. Materials and Methods. The morphology of seabed at Bouchard zone was carried out using a portable side-scan sonar EdgeTech Discover 4150, and profiles of the substrate up to $c .210 \mathrm{~m}$ depth below seabed were obtained with a portable subbottom profiler EdgeTech Discover SB-3200XS. Both instruments were towed and operated using small rubber boats (Zodiac Mark III), while the sampling at Weddell zone was done onboard the Icebreaker Irizar.

Sediment samples were obtained with snapper and gravity and piston corer Benthic of $10 / 20 \mathrm{~kg}$ and packaged in sealed containers. Benzalkonium chloride $2 \%$ was added to inhibit bacterial action and forwarded to the laboratory [10], where all the sediment samples were analyzed for their contents in gaseous alkanes: methane $(\mathrm{C} 1)$, ethane $(\mathrm{C} 2)$, propane $(\mathrm{C} 3)$, butane $(\mathrm{C} 4)$, and pentane $(\mathrm{C} 5)$.
Additionally, samples of gas exhalations, found at Bouchard zone, were obtained with gas trap; they were packaged in sealed containers of 4 liters' capacity and sent to laboratory in order to be analyzed for their contents in methane, $\mathrm{H}_{2} \mathrm{~S}$, and $\mathrm{CO}_{2}$.

\section{Results}

Sediment samples from the seabed in the surroundings of the NE Antarctic Peninsula (Figure 1) contain small amounts of methane $\left(\mathrm{CH}_{4}\right)$, besides other aliphatic hydrocarbons of simple bond and ice. Most of the samples analyzed in this paper (Table 1) are fine grained and generally muddy (silty clay) and exhibit dark gray colour, except those obtained at shallow areas next to the coast (Bouchard zone, Figure 1), where they include sandy fractions and show lighter shades. Also, some samples from deeper water $(c .300 / 450 \mathrm{~m})$ in Weddell zone (Figure 1) show high contents of sand and gravel materials. The latter are composed of fragments of basalts identified to belong to James Ross Island Volcanic Group (JRIVG) and plutonic rocks (mainly granites), all of them were probably transported by icebergs (dropstones).

At Bouchard zone, 88 samples from the seabed, obtained at depths between $0.5 \mathrm{~m}$ and $37 \mathrm{~m}$, were analyzed (Table 1 , Figures 2 and 11). The $\mathrm{Cl}\left(\mathrm{CH}_{4}\right)$ content ranges between $115 \mathrm{ppm}$ and 9,995 ppm, with $423 \mathrm{ppm}$ in average (Table 1, Figure 2). Methane ( $\mathrm{Cl})$ is the dominant gaseous alkane hydrocarbon in all the samples (Figure 3). Four samples show high values of methane ranging between $513.89 \mathrm{ppm}$ and $9995.93 \mathrm{ppm}$ and they are considered as strongly positive anomalies (Figure 2). Also, in all samples, small amounts of more complex hydrocarbons from ethane $(\mathrm{C} 2)$ to pentane (C5) (Table 1) were detected.

The hydrocarbons ratio $(R=\mathrm{C} 1 / \mathrm{C} 2+\mathrm{C} 3)$ exhibits values ranging between 2 and 41 , whereas the percentage of $\mathrm{C} 1$ to total gaseous hydrocarbons $(\% \mathrm{Cl}=\mathrm{C} 1 * 100 / \mathrm{C} 1+\mathrm{C} 2+\mathrm{C} 3$ + C4 + C5) fluctuates between $63.44 \%$ and $99.89 \%$ (Table 1 , Figure 3).

Many gas emanations (bubbling) were detected at Bouchard zone, where the composition of a total of six (6) gas samples yielded c. 160,000 ppm as an average of $\mathrm{CH}_{4}$, with traces of $\mathrm{H}_{2} \mathrm{~S}$ and $\mathrm{CO}_{2}$ (Table 2). These gas samples were collected in shallow waters ranging $10-15 \mathrm{~m}$ in depth, mainly during low tides, when gas emanations occur more frequently, suggesting that free gas might accumulate in shallow submarine reservoirs during high tides and escape as water pressure decreases below certain level.

The supplemental video shows the coastal environment during low tide in the vicinity of Seymour Island (at Bouchard zone, Figure 1), located at the NW extreme of the Weddell Sea. Images of various natural bubbling of methane are also shown. The water depth was about $1.5 \mathrm{~m}$ and the water temperature was $-1.6^{\circ} \mathrm{C}$. The images were obtained during the Antarctic summer campaign of the year 2012. The density of the methane leaks was estimated at approximately 1 methane vent every 20 square meters.

At Weddell zone (Figure 1), 54 sediment samples, obtained at water depths of $289-556 \mathrm{~m}$, were analyzed (Table 1, Figures 4, 5, and 12). Methane (C1) content ranging 
TABLE 2: Analyses of gas emanations (bubbling) at Bouchard zone (Figure 1).

\begin{tabular}{lcccc}
\hline \multirow{2}{*}{ Samples } & Bouchard zone & \multicolumn{3}{c}{ Analyzed gases } \\
$\mathrm{SH}_{2}$ & $\mathrm{C}$ & \multicolumn{2}{c}{$\mathrm{CO}_{2}$} \\
\hline 1 & Depth & $\mathrm{C}(\mathrm{ppm})$ & Traces & Traces \\
2 & $10-15 \mathrm{~m}$ & 165,240 & Traces & Traces \\
3 & $10-15 \mathrm{~m}$ & 169,263 & Traces & Traces \\
4 & $10-15 \mathrm{~m}$ & 167,806 & Traces & Traces \\
5 & $10-15 \mathrm{~m}$ & 166,570 & Traces & Traces \\
6 & $10-15 \mathrm{~m}$ & 158,172 & Traces & \\
\hline
\end{tabular}

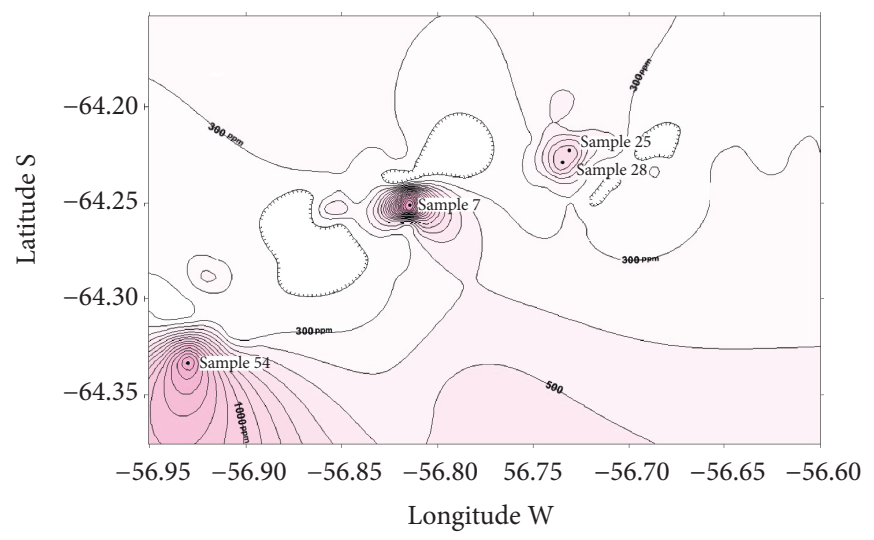

FIGURE 2: Distribution of methane $\left(\mathrm{CH}_{4}\right)$ detected in samples of seabed sediments along Bouchard zone (Figure 1). Samples 7, 54, 25, and 28 are considered as strongly positive anomalies; they contain the maximum values of methane: $9,995 \mathrm{ppm}, 1,753 \mathrm{ppm}, 858 \mathrm{ppm}$, and $837 \mathrm{ppm}$, respectively.

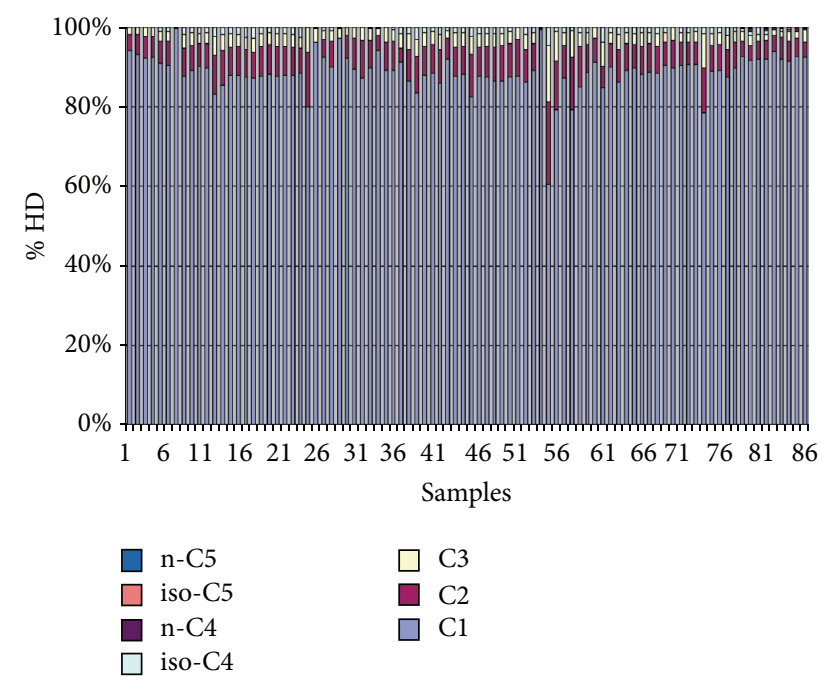

Figure 3: Percentage of methane $\left(\mathrm{CH}_{4}\right)$ related to total hydrocarbons content $(\% \mathrm{HD}=\mathrm{C} 1 * 100 / \mathrm{C} 1+\mathrm{C} 2+\mathrm{C} 3+\mathrm{C} 4+\mathrm{C} 5)$ detected in all analyzed samples along Bouchard zone (Figure 1). C1: methane, $\mathrm{C} 2$ : ethane, $\mathrm{C} 3$ : propane, $\mathrm{C} 4$ : butane, $\mathrm{n}-\mathrm{C} 4$ : n-butane, $\mathrm{C} 5$ : pentane, and n-C5: n-pentane.

between 65.27 and $1753.87 \mathrm{ppm}$, with $369.60 \mathrm{ppm}$ as an average, was detected (Table 1, Figure 4), being the dominant gaseous aliphatic alkane in all samples (Figure 5). Samples with high values (i.e., Sample 20: 1,753.87 ppm) are considered as strongly positive anomalies. Small amounts of other alkane hydrocarbons, from ethane $(\mathrm{C} 2)$ to pentane $(\mathrm{C} 5)$, were also detected (Table 1, Figure 5). Values of $R$ vary between 2 and 24, while the values of $\mathrm{C} 1$ vary between $70 \%$ and $95 \%$ (Figure 5). No gas vents (flares) were observed along this sector.

Reflectors compatible with lenses and discontinuous bands, next to the sea floor, were detected by geophysical surveys (see "Section 1.4, Materials and Methods") in the substrate of Admiralty Sound, Antarctica (Bouchard zone) (Figures 6, 7(a), 7(b), and 8). Instrumental limitations in the survey only allowed for recognizing reflectors into the substrate up to a maximum of $210 \mathrm{~m}$ depth below the seabed (Figure 8), but it is estimated that the presence of such reflectors still continues below this range. In this area, the maximum content of $\mathrm{CH}_{4}$ was obtained (Sample 7: 9,995.93 ppm, Table 1, Figure 2) from all the samples analyzed in this paper.

The distribution of the reflectors detected in the substrate at Bouchard zone is heterogeneous and apparently random (Figures 6 and 8). The horizontal trace of the geophysical surveys was fragmentary, quite irregular, and discontinuous due to the obstacle presented by sea ice and icebergs.

Images of the seabed, obtained with side-scan sonar in shallow waters of Bouchard zone, show a dense network of tracks and drags caused by the intense traffic of icebergs 


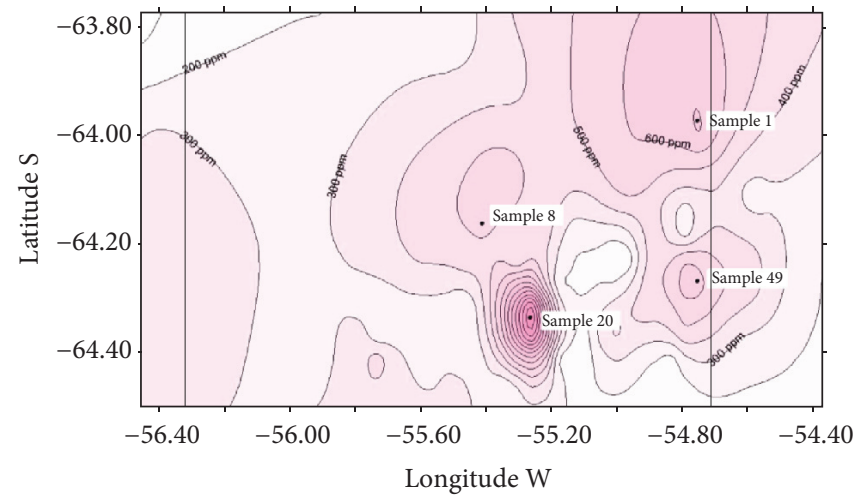

FIGURE 4: Distribution of methane $\left(\mathrm{CH}_{4}\right)$ detected in seabed sediments along Weddell zone (Figure 1). Samples 20, 49, 1, and 8 are considered as strongly positive anomalies; they contain the maximum values of methane: 1,753 ppm, 717 ppm, 709 ppm, and 592 ppm, respectively.

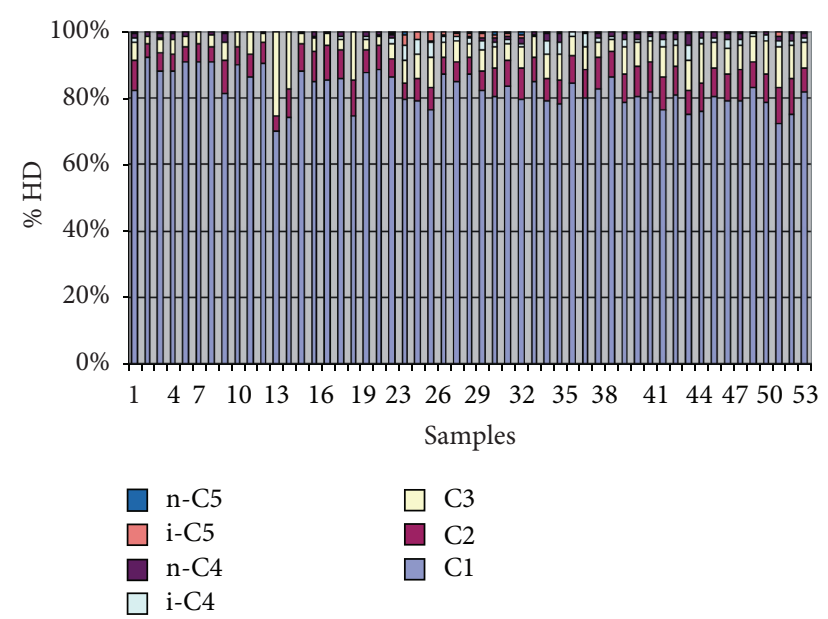

Figure 5: Percentage of methane $\left(\mathrm{CH}_{4}\right)$ related to total hydrocarbons content $(\% \mathrm{HD}=\mathrm{C} 1 * 100 / \mathrm{C} 1+\mathrm{C} 2+\mathrm{C} 3+\mathrm{C} 4+\mathrm{C} 5)$ detected in all analyzed samples along Weddell zone (Figure 1). C1: methane, C2: ethane, C3: propane, C4: butane, n-C4: n-butane, C5: pentane, and n-C5: n-pentane.

(Figure 9). The strong mechanical disturbance obliterates most of the structures formed on the seabed by the venting of gases ("pockmarks"). Figure 10 shows images obtained with portable side-scan sonar, of these structures quite well preserved at seabed of Bouchard zone.

No geophysical research was carried out at Weddell zone, due to the lack of facilities and adequate instrumental onboard the Icebreaker Irizar.

\section{Discussion}

Methane (C1) predominates widely in sediments of the Antarctic seabed, analyzed in this paper. The average content of $\mathrm{C} 1$ to total gaseous hydrocarbons $(\mathrm{C} 1+\mathrm{C} 2+\mathrm{C} 3+\mathrm{C} 4+$ C5) in Bouchard and Weddell zones is c. $89 \%$ and c. $82 \%$, respectively, indicating a certain abundance of more complex hydrocarbons, predominantly ethane (C2) and propane (C3) at both zones. This is also reflected in the relatively low values of $R$ (ratio of [C1]/[C2] + [C3]) which is $2-41$ (average value

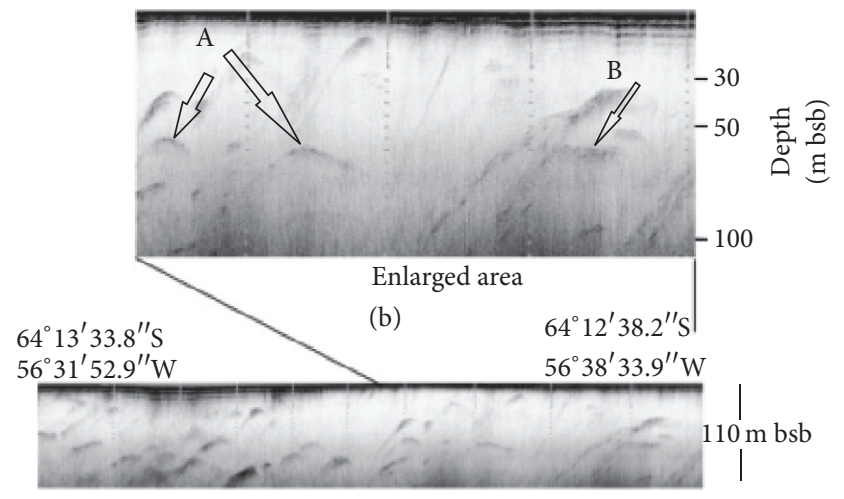

Towards $31.82^{\circ} \mathrm{NE}$, length $2 \mathrm{~km}$

(a)

Figure 6: Reflectors compatible with solid lenses (A) and discontinuous bands (B), recorded with sea-bottom portable profiler (EdgeTech Discover SB-3200-XS), in a sector of marine substrate up to $110 \mathrm{~m}$ below seabed (bsb), towards the NE of Bouchard zone (Figure 1). These reflectors may correspond to methane accumulations frozen in the marine substrate, surroundings of Seymour (Marambio) Island (Figure 1). (a) A survey sector of the marine substrate, $2 \mathrm{~km}$ long and $110 \mathrm{~m}$ depth. Latitude and longitude are specified at both the left and right corners of the profile. (b) Enlarged sector of the figure (a).

equals 23) at Bouchard zone and 2-24 (average value equals 7) at Weddell zone (Table 1).

Although there is not a definite design in the distribution of methane concentrations, at Bouchard zone, a gradual increase of methane content occurs as sampling stations migrate northwards from the coast of Seymour Island (Figure 2).

At Bouchard zone, there is no relationship between methane content and sea depth (Figures 11 and 12). Methane concentrations are lower near the coasts of Seymour Island, where sandy sediments predominate, while they are higher in seabed sediments rich in mud, generally away from this coast. This situation is also reflected in Fossil Bay ("Bahía Fósil") (Figures 1 and 2), where muddy clay facies predominate and gas concentrations are relatively high. In the proximities of 


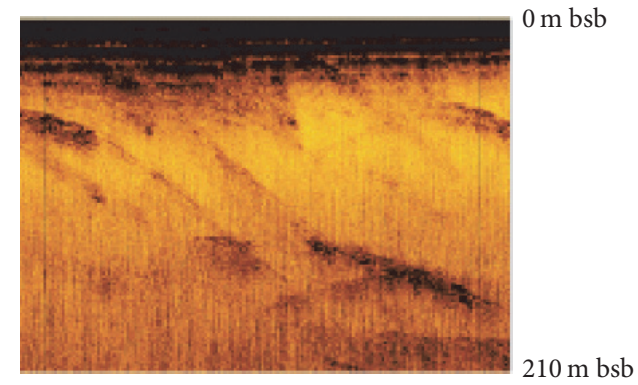

Lat. $64^{\circ} 12.9682^{\prime} S$, Long. $58^{\circ} 38.8427^{\prime} \mathrm{W}$, water depth $34.8 \mathrm{~m}$

(a)

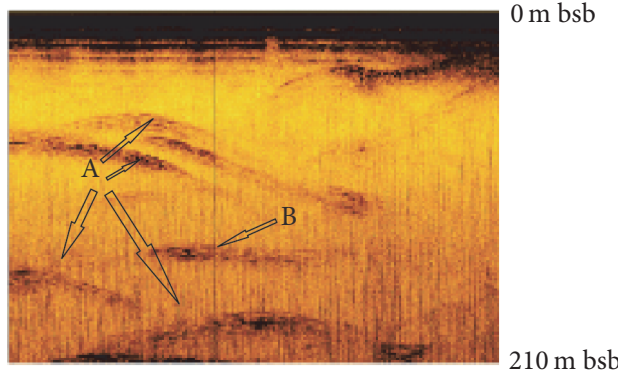

Lat. $64^{\circ} 12.9584^{\prime}$ S, Long. $58^{\circ} 387221^{\prime} \mathrm{W}$, Water depth $35 \mathrm{~m}$

(b)

FigurE 7: Details of reflectors compatible with lenses (A) and solid bands (B), recorded with sea-bottom portable profiler (EdgeTech Discover SB-3200-XS), in a sector of marine substrate, up to $210 \mathrm{~m}$ depth below seabed (bsb), towards the NE of Bouchard zone (Figure 1). These reflectors may correspond to methane accumulations, frozen in the marine substrate at the surroundings of Seymour (Marambio) Island. Latitude, longitude, and depth indicated below correspond to the one at the middle point of each graph.

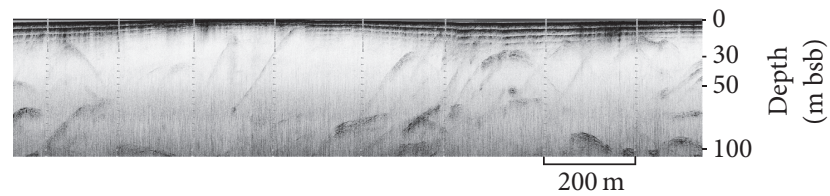

Figure 8: Reflectors recorded with sea-bottom portable profiler (EdgeTech Discover SB-3200-XS) at Bouchard zone (Figure 1). The randomized distribution of reflectors is shown in the substrate up to $110 \mathrm{~m}$ below seabed (bsb).

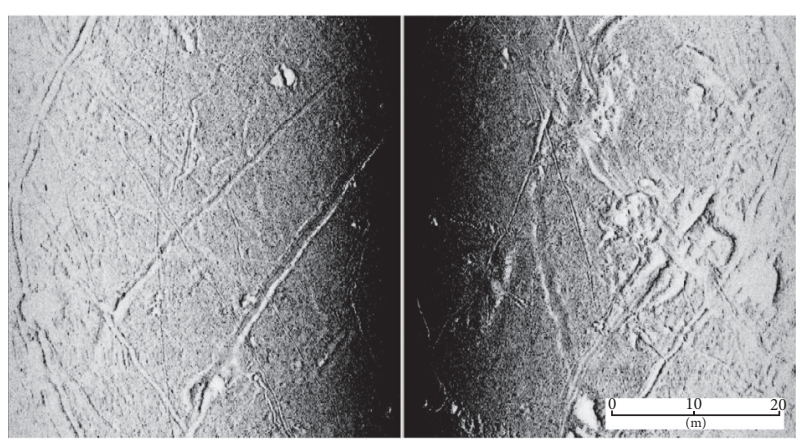

FIGURE 9: Images of seabed obtained with side scan sonar in shallow waters (c. $15 \mathrm{~m}$ depth) at Bouchard zone (Figure 1). A dense network of drag marks caused by the heavy traffic of icebergs is shown.

Seymour Island, low methane concentrations are probably due to faster gas escapes from sandy sediments, which prevail there. This fact contrasts with the highest content of gaseous hydrocarbons in the muddy facies far from the island. In Weddell zone (Figures 1 and 4), the relationship between higher contents of gaseous hydrocarbons and muddy facies is also manifested, while coarse-grained facies (sand and gravel) are poorer in these gases.

According to Mienert et al. [11], in shallow water, methane is transferred to the water column from the sea bottom and may be incorporated into the atmosphere. This situation coincides with observations done between years 1994 and 2015 in

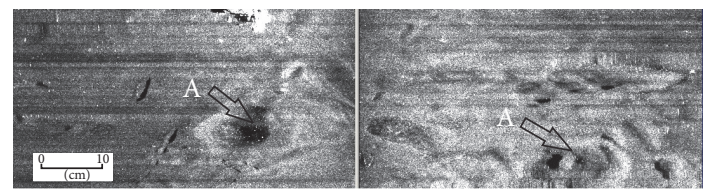

FIGURE 10: Images of seabed obtained with side scan sonar in shallow waters (c. $8 \mathrm{~m}$ depth) at Bouchard zone (Figure 1). A: round shapes ("pockmarks") associated with fixed leakages of methane.

shallow waters at Bouchard zone where numerous gas vents occur, reaching the atmosphere and being predominantly methane (c. 160,000 ppm, c. 16\%) and traces of $\mathrm{CO}_{2}$ and $\mathrm{H}_{2} \mathrm{~S}$ (Table 2). These gas vents and the presence of mainly methane gas in seabed sediments are compatible with the speculation of Macdonald et al. [4] about the existence of gas reservoirs in the substrate of the "shallow play zone" of Larsen Basin (James Ross Basin) (see "Section 1.3, Geological Frame").

Another research directly related to this paper, which supports the existence of a frozen substrate or al least the presence of significant amounts of ice, was conducted by Silva Busso et al. [12]. They detected by geoelectric methods (i.e., $1 \mathrm{D}$ and $2 \mathrm{D}$ vertical electrical sounding: resistive electrical tomography) the presence of criopeg sectors (interbedded fresh and salty ice) and sectors with relict and discontinuous permafrost in the coastal and intertidal substrate at the López de Bertodano Bay, Seymour Island (Bouchard zone, Figure 1). Here, the tidal range was $c .2 \mathrm{~m}$, reaching $c .3 \mathrm{~m}$ during tides of syzygy. Sands and silts with high to moderate ice content were found in the substrate up to a depth of $c .-85 \mathrm{~m}$ bsl (maximum range of the instruments). The maximum ice content was found between -65 and $-85 \mathrm{~m}$ bsl.

The abundant presence of ice within the substrate provides a possible mechanism to explain natural bubbling methane observed in the area (Figure 1, Bouchard zone). Methane would be contained in underground reservoirs at relatively shallow depths (c. 100-300 m bsl), which remain stable while the ice box remains frozen, being released when certain conditions vary, mainly increase in temperature. 


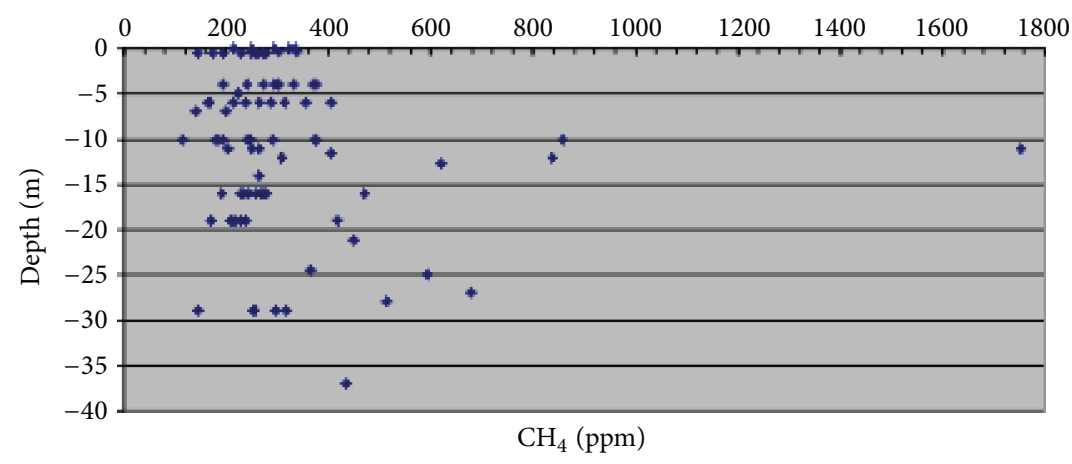

Figure 11: Random distribution of concentrations of $\mathrm{CH}_{4}(\mathrm{ppm})$ versus water depth $(\mathrm{m})$ at Bouchard zone is shown (Figure 1). Sample 7 is not represented on this plot, since its maximum positive value of $\mathrm{CH}_{4}(9,995 \mathrm{ppm})$ is out of scale. The average $\mathrm{CH}_{4}$ concentration is $423.31 \mathrm{ppm}$ at a depth of $c .-15 \mathrm{~m}$.

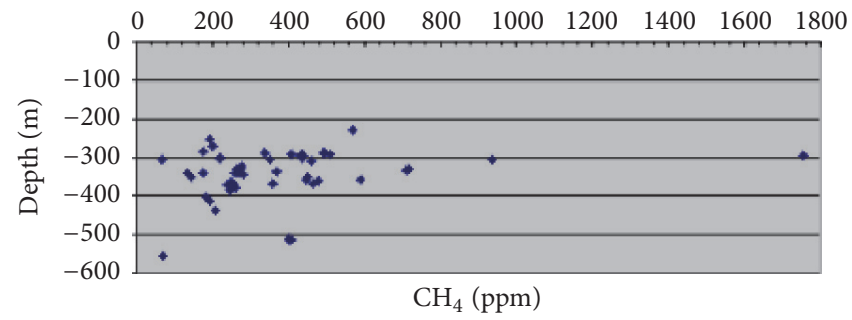

FIGURE 12: Random distribution of concentrations of $\mathrm{CH}_{4}(\mathrm{ppm})$ versus water depth ( $\mathrm{m}$ ) at Weddell zone is shown (Figure 1). Sample 20 is not represented on this plot, since its maximum positive value of $\mathrm{CH}_{4}(1,753 \mathrm{ppm})$ is out of scale. The average $\mathrm{CH}_{4}$ concentration is $369.60 \mathrm{ppm}$ at a depth of $c .-350 \mathrm{~m}$.

\section{Conclusions}

The presence of gaseous hydrocarbons (from $\mathrm{C} 1$ to $\mathrm{C} 5$ ) in seabed sediments (Table 1) and the bubbling of methane (Table 2) suggest the presence of gas accumulations in the substrate of the marine areas investigated in this study. It is in part compatible with the ideas supported by Macdonald et al. [4], who inferred that in this area shallow hydrocarbon reservoirs would contain potentially mainly gas.

The release of methane from the frozen ocean substrate, adjacent to Seymour Island, would be linked to climate instability during Late Cenozoic, when vast areas of the Antarctic continental shelf were flooded during a marine transgression which occurred c. 18,000 years ago, after the Last Glacial Maximum (LGM). Thus, the heat flow from the sea to the marine substrate, now flooded, would have destabilized frozen gas accumulations, which were originally formed into terrestrial permafrost during the LGM, a similar process that occurred in the Arctic [13].

Methane vents bubbling from seafloor were observed off shore some Antarctic islands coasts located at the NW extreme of Weddell Sea (i.e., Seymour Island). Methane emanations (bubbles) were more strong and abundant mainly during low tides, when gas emanations occurred more frequently, suggesting that free gas might accumulate in some shallow submarine reservoirs during high tides, venting as water pressure decreases below certain level.

Additionally, the extraordinary rapid climate warming which is occurring in the northern tip of the Antarctic
Peninsula [14-18] would have helped to accelerate the destabilization and melting of the frozen gas contained into the shallow marine substrate of the area. The consequences of this warming can largely be seen in the reduction of land ice along West Antarctica and the ice shelves destruction in the surrounding seas (e.g., $[19,20])$. Recent temperatures are extremely high, setting a new record of $+16.5^{\circ} \mathrm{C}$ in March 2015 (Meteorological Station at Esperanza Base, Argentinean Antarctic station), this is an event without precedent during the Holocene [14].

\section{Competing Interests}

The authors declare that there is no conflict of interests regarding the publication of this paper.

\section{Authors' Contributions}

(1) Rodolfo Augusto del Valle, and E. Yermolin contributed to data acquisition, information processing, and production of results. (2) Jessica Chiarandini and Á. Sánchez Granel contributed to the processing of chemical information and production of results. (3) Jorge Carlos Lusky performed the geophysical data acquisition.

\section{Acknowledgments}

The authors are grateful to every one who helped/participated in this paper and especially Dr. Umberta Tinivella (OGSTrieste, Italy) who helped to improve the manuscript. 


\section{References}

[1] Lance361, "Methane the other important greenhouse gas," 2015, https://lance361.wordpress.com/2015/10/27/methane-the-otherimportant-greenhouse-gas/.

[2] D. H. Elliot, "Tectonic setting and evolution of the James Ross Basin, northern Antarctic Peninsula," Memoir - Geological Society of America, vol. 169, pp. 541-555, 1988.

[3] R. A. del Valle, D. H. Elliot, and D. I. M. Macdonald, "Sedimentary basins on the east flank of the Antarctic Peninsula: proposed nomenclature," Antarctic Science, vol. 4, pp. 477-478, 1992.

[4] D. I. M. Macdonald, P. F. Barker, S. W. Garrett et al., "A preliminary assessment of the hydrocarbon potential of the Larsen Basin, Antarctica," Marine and Petroleum Geology, vol. 5, no. 1, pp. 34-53, 1988.

[5] P. H. H. Nelson, "The James Ross Island Volcanic Group of northeast Graham Land," British Antarctic Survey Scientific Reports 54, 1966.

[6] E. Borzotta and D. Trombotto, "Correlation between frozen ground thickness measured in Antarctica and permafrost thickness estimated on the basis of the heat flow obtained from magnetotelluric soundings," Cold Regions Science and Technology, vol. 40, no. 1-2, pp. 81-96, 2004.

[7] M. Fukuda, J. Strelin, K. Shimokawa, N. Takahashi, T. Sone, and D. Tromboto, "Permafrost occurrence of Seymour Island and James Ross Island, Antarctic Peninsula Region," in Recent Progress in Antarctic Earth Science, Y. Yoshida, Ed., pp. 631-636, Terra Scientific Publishing Company, Tokyo, Japan, 1992.

[8] B. J. Sloan, L. A. Lawver, and J. B. Anderson, "Seismic stratigraphy of the Larsen Basin, eastern Antarctic Peninsula," Antarctic Research Series, vol. 68, pp. 59-74, 1995.

[9] R. A. Del Valle and H. Miller, "Transpressional deformation along the margin of Larsen Basin: new data from Pedersen Nunatak, Antarctic Peninsula," Antarctic Science, vol. 13, no. 2, pp. 158-166, 2001.

[10] Synergic Petroleum Technologies S.A., IPS-Integrated Petroleum Solutions, Paraguay.

[11] J. Mienert, J. Posewang, and M. Baumann, "Gas hydrates along the northeastern Atlantic margin: possible hydrate-bound margin instabilities and possible release of methane," Geological Society Special Publication, vol. 137, pp. 275-291, 1998.

[12] A. Silva Busso, Y. Yermolin, and T. Manograsso Czalbowski, "Características del permafrost costero (criopeg) con el uso de técnicas geoeléctricas, arroyo Díaz, isla Marambio, península Antártica," Revista de la Asociación Geológica Argentina, vol. 70, no. 4, pp. 583-595, 2013.

[13] C. D. Ruppel, "Methane hydrates and contemporary climate change," Nature Education Knowledge, vol. 3, no. 10, article 29, 2011.

[14] F. Fernandoy, H. Hanno Meyer, G. Gacitua, C. Cardenas, and U. Falk, "High-resolution climate information from the northern Antarctic Peninsula as revealed by shallow firn cores and geophysical data," in Proceedings of the 12th International Symposium on Antarctic Earth Sciences (XII ISAES '15), S18 Palaeoenvironmental Changes in Antarctica and Southern Oceans since the Last Glacial Maximum, Abstract 510, pp. 418486, 2015.

[15] B. J. Davies, J. L. Carrivick, N. F. Glasser, M. J. Hambrey, and J. L. Smellie, "Variable glacier response to atmospheric warming, northern Antarctic Peninsula, 1988-2009," Cryosphere, vol. 6, no. 5, pp. 1031-1048, 2012.
[16] N. F. Glasser, T. A. Scambos, J. A. Bohlander, M. Truffer, E. C. Pettit, and B. J. Davies, "From ice-shelf tributary to tidewater glacier: continued rapid glacier recession, acceleration and thinning of Röhss Glacier following the 1995 collapse of the Prince Gustav Ice Shelf on the Antarctic Peninsula," Journal of Glaciology, vol. 57, no. 203, pp. 397-406, 2011.

[17] J. Turner, S. R. Colwell, G. J. Marshall et al., "Antarctic climate change during the last 50 years," International Journal of Climatology, vol. 25, no. 3, pp. 279-294, 2005.

[18] M. R. van den Broeke and N. P. M. van Lipzig, "Changes in Antarctic temperature, wind and precipitation in response to the Antarctic Oscillation," Annals of Glaciology, vol. 39, pp. 119126, 2004.

[19] E. Rignot, "Changes in West Antarctic ice stream dynamics observed with ALOS PALSAR data," Geophysical Research Letters, vol. 35, no. 12, 2008.

[20] E. Rignot, J. L. Bamber, M. R. Van Den Broeke et al., "Recent Antarctic ice mass loss from radar interferometry and regional climate modelling," Nature Geoscience, vol. 1, no. 2, pp. 106-110, 2008. 

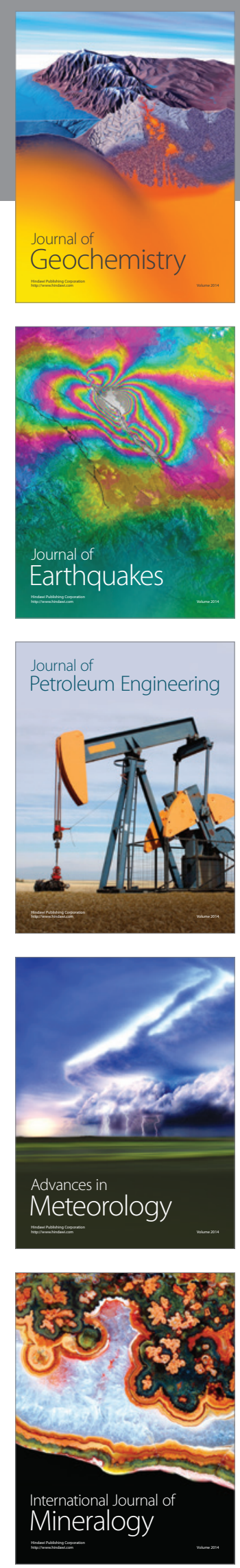
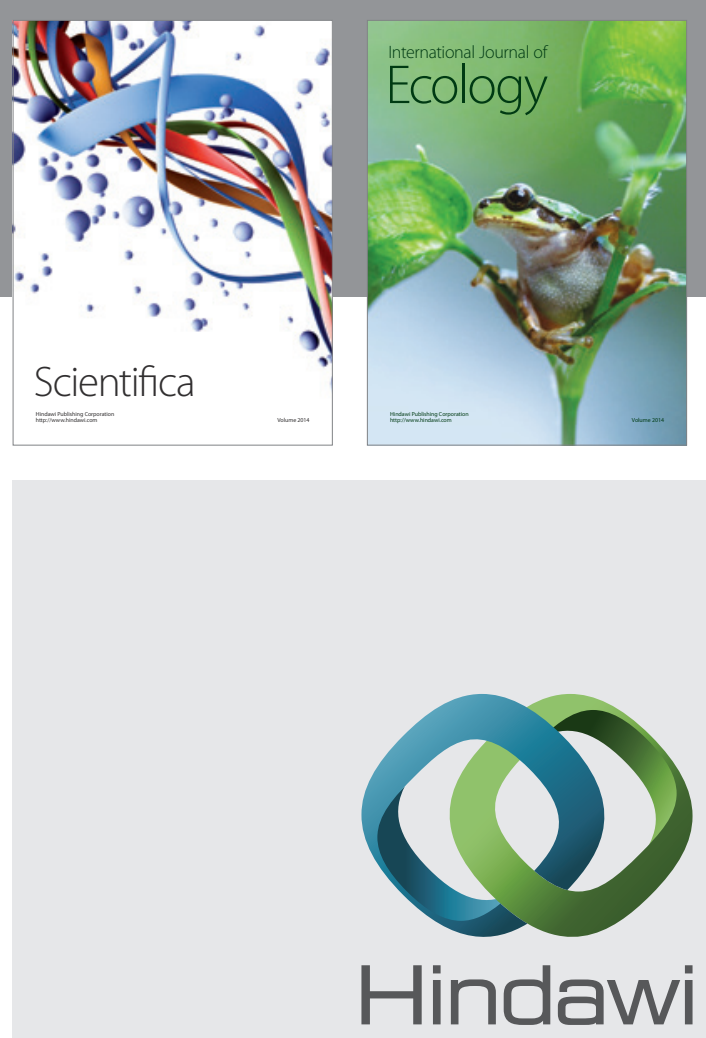

Submit your manuscripts at

https://www.hindawi.com
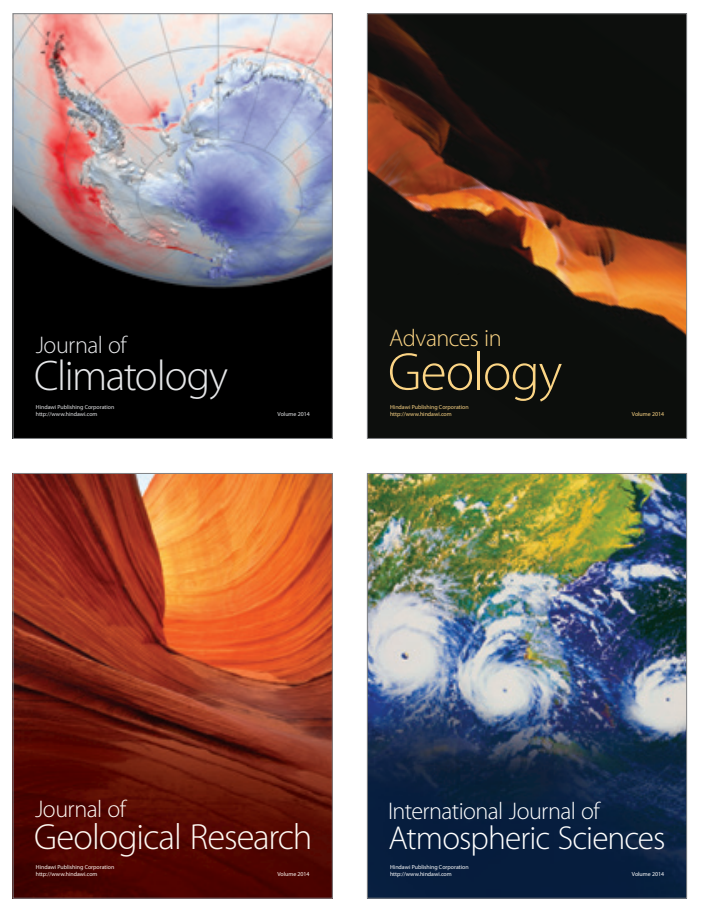

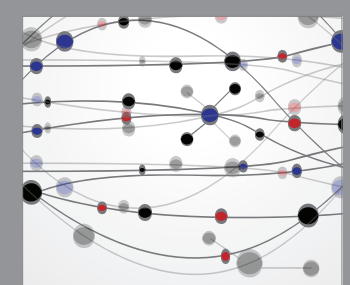

The Scientific

\section{World Journal}
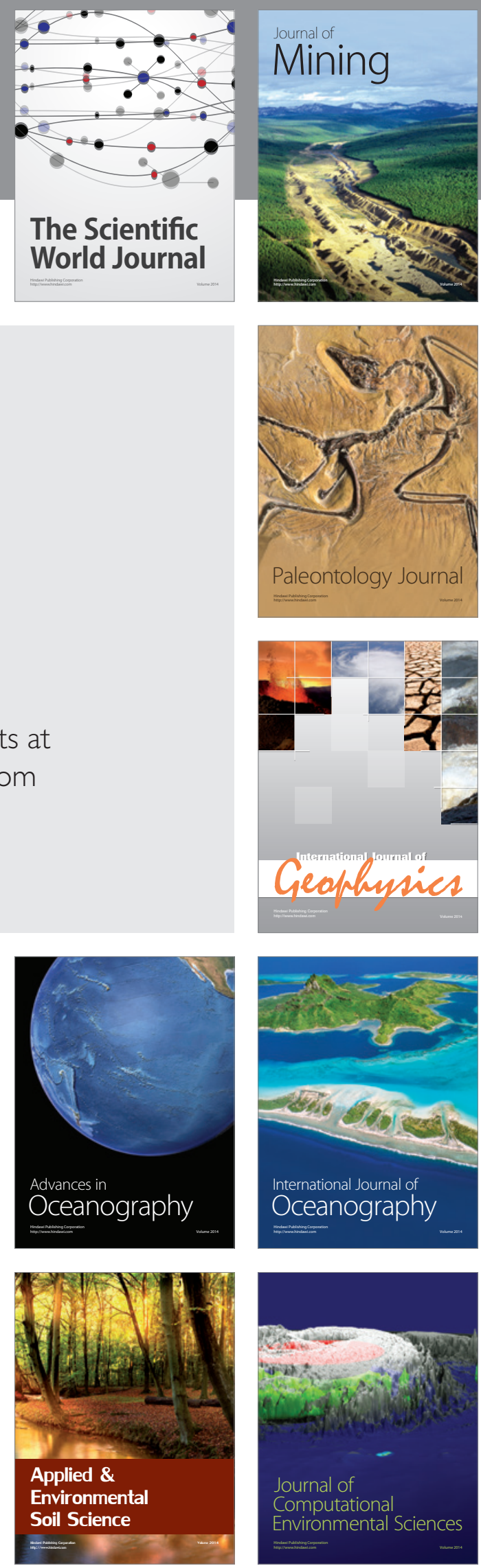